\title{
DEVELOPMENT OF CHROMATOGRAPHIC METHODS FOR THEBAINE DETECTION AND QUANTIFICATION ALONG WITH SOME OF RELATED ALKALOID DERIVATIVES
}

\author{
Marija Spasevska $^{1,2}$, Jane Bogdanov ${ }^{2 *}$, Hristina Babunovska ${ }^{1}$ \\ ${ }^{1}$ Alkaloid AD Skopje - Pharmaceutical, Chemical, Cosmetic \& Botanical Industry, \\ AleksandarMakedonski No. 12, Skopje, Republic of Macedonia \\ ${ }^{2}$ Institute of Chemistry, Faculty of Natural Sciences and Mathematics, Ss. Cyril and Methodius University, \\ Arhimedova 5, MK-1001, Skopje, Republic of Macedonia \\ j_b_bogdanov@yahoo.com,mspasevska@alkaloid.com.mk
}

\begin{abstract}
A RP-HPLC-UVD method for qualitative analysis and quantification of thebaine was developed utilizing RP-C18 monolithic column, gradient elution with trifluoroacetic acid and formic acid in water and in acetonitrile and detection wavelength of $285 \mathrm{~nm}$. The effects of the relevant chromatographic conditions were investigated and the optimized and validated method was used for analysis of three in-house prepared batches of thebaine. Additionally, a complementary GC-MS method was developed for identification of thebaine and potential impurities. In parallel the batches were analyzed by routine methods for preliminary quality assessment based on physical and spectroscopic properties (melting point, specific optical rotation, UV-Vis and IR spectroscopy). There was correlation between the samples purity as determined by the developed HPLC method and the melting point ranges. The HPLC method herein presented is suitable for routine quantitative analysis regardless of the method of thebaine preparation and it is suitable for its corresponding free base or salt form. Additionally, considering the mobile phase compatibility, it can be adapted/transferred easily for HPLC-MS analysis, especially if the identity of the impurities needs to be determined.
\end{abstract}

Keywords: thebaine; HPLC; purity; GC-MS; physical properties; spectroscopic properties;

\section{РАЗВОЈ НА ХРОМАТОГРАФСКИ МЕТОДИ ЗА ДЕТЕКЦИЈА И КВАНТИФИКАЦИЈА НА ТЕБАИН ЗАЕДНО СО НЕКОИ СРОДНИ АЛКАЛОИДНИ ДЕРИВАТИ}

Методата RP-HPLC-UVD за квалитативна анализа и квантификација на тебаин е развиена co користење на монолитна колона RP-C18. Методата е со градиентна елуција со трифлуорооцетна и мравја киселина во вода и ацетонитрил и со детекција на $285 \mathrm{~nm}$. Беа евалуирани ефектите на релевантните хроматографски услови и оптимизираната и валидирана метода беше применета за анализа на три подготвени серии тебаин. Дополнително беше развиена комплементарна GC-MS метода за идентификација на тебаин и потенцијалните нечистотии. Паралелно со хроматографските методи, примероците на тебаин беа анализирани со рутински методи за прелиминарно одредување на квалитет, базирани на физички и спектроскопски својства (температура на топење, оптичка ротација, УВ-видлива и инфрацрвена спектроскопија). Постои корелација помеѓу чистотата на примероците одредена со HPLC и соодветните опсези на температурите на топење. Прикажаната HPLC метода е соодветна за рутинска анализа без разлика на методата на подготовка и може да се користи за тебаин како слободна база и за негови соли. Додатно, ако се земе предвид компатибилноста на мобилната фаза, развиената метода лесно може да се адаптира/трансферира за анализи со HPLC-MS, особено ако е потребно да се одреди идентитетот на нечистотиите.

Клучни зборови: тебаин; HPLC; GC-MS; физички својства; спектроскопски својства; 


\section{INTRODUCTION}

Thebaine belongs to the group of plantderived natural products containing basic nitrogen called alkaloids. These opium alkaloids are often used in everyday life, medicine and pharmaceutical industry because of their (sometimes spectacular) pharmacological effects; but one should be careful because most of them are toxic especially to other organisms [1-4]. They can be purified from crude extracts by acid-base extraction and most often they are extracted from the poppy capsules of Papaver somniferum L. by two commercial methods. The first method produces opium-dried latex collected from the wound of an immature capsule after it has been cut. The second method for alkaloid purification uses the mature poppy capsules and stems which are collected than threshed to remove the seeds and form a straw. The straw is dried, if necessary, to about $15 \%$ and then water or solvent extraction is employed to extract the alkaloids from the straw [1-4]. According to the Merck Index, the opium and the straw from the usually grown Papaver somniferum L. on dry basis contain thebaine in commercially useful concentration [5]. The amounts of the present alkaloids in opium and straw are given in Table 1. Even though there are plant varieties that give higher yields of thebaine, the main goal is to extract thebaine from the more common species that are commercially used for obtaining morphine.

\section{Table 1}

Composition of alkaloids in \% in opium and straw

\begin{tabular}{ccc}
\hline \hline$\%(\boldsymbol{m} / \boldsymbol{m})$ of alkaloid & Opium & Straw \\
\hline Morphine & $10-16$ & $1-3$ \\
Codeine & $0.8-2.5$ & $0.05-0.3$ \\
Thebaine & $0.5-2$ & $0.15-0.65$ \\
Oripavine & $0-0.1$ & $0-0.05$ \\
\hline \hline
\end{tabular}

Thebaine, as shown before in Table 1, is present in very small amounts in the opium and straw and morphine is the major alkaloid that is extracted from capsules of the poppy plant of Papaver somniferum $\mathrm{L}$. This is one of the reasons for the limited availability of thebaine and its high cost. Alternatively, thebaine can be produced in high yields and in a highly pure form by a multistep synthesis that utilizes codeine or a codeine salt as the starting material [1-6]. Although these semisyntheses are effective, the availability of thebaine is limited by its high cost because the total synthesis requires many steps. That is the main reason that the supply of thebaine is limited to some fraction of the demand for morphine.

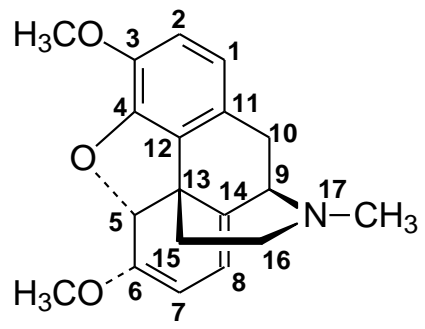

Fig. 1. Chemical structure of thebaine (6,7,8,14-tetradehydro4,5a-epoxy-3,6-dimethoxy-17-methylmorphinan)

Usually in the opium several alkaloids other than thebaine are present: morphine (2), pseudomorphine (3), codeine (4), oripavine (5), papaverine (6) and noscapine (7). It is important to note that the $N$-oxides of the more abundant alkaloids (morphine, codeine, thebaine and oripavine) may also be present. Important opiate derivatives such as hydrocodone and the ring-C bridged compounds buprenorphine and etorphine are most practically prepared from thebaine. Being an important starting material for many useful compounds, particularly 14-hydroxy-substituted morphine derivatives that are important narcotic analgesics and/or antagonists, e.g. oxycodone, oxymorphone, nalbuphine, naloxone, naltrexone and nalmefene, the demand of thebaine is increasing [1-4]. The main properties of thebaine and related alkaloids are given in Table $2[5,6]$.

A literature survey for thebaine analysis (identification, quantification and characterization of its impurities) revealed very little defined methods dedicated strictly to analysis of thebaine. Various analytical methods have been reported and published which refer to thebaine or other alkaloid analysis and determination from Papaver plants like somniferum or bracteatum [7-13]. For instance, there are published methods for determination of alkaloids in Papaver somniferum and thebaine using HPLC with chemiluminescence detection [14-16], capillary electrophoresis analysis [17, 18], infrared and Raman spectroscopy of alkaloids [19], infrared and ultraviolet spectroscopic determination [20] and configurational analysis of thebaine [21]. There are also other methods described in the literature, such as oxidative colorimetric analysis [22], determination of opiates by circular dichroism [23], colorimetric determination [24], TLC analysis of opiate alkaloids and drugs [25, 26], ELISA (enzyme-linked immunosorbent assay) analysis of thebaine [27], FTIR spectroscopy of opiates and chemometric analysis [28], differential pulse polarography [29] and even a voltammetric analysis of thebaine [30]. 

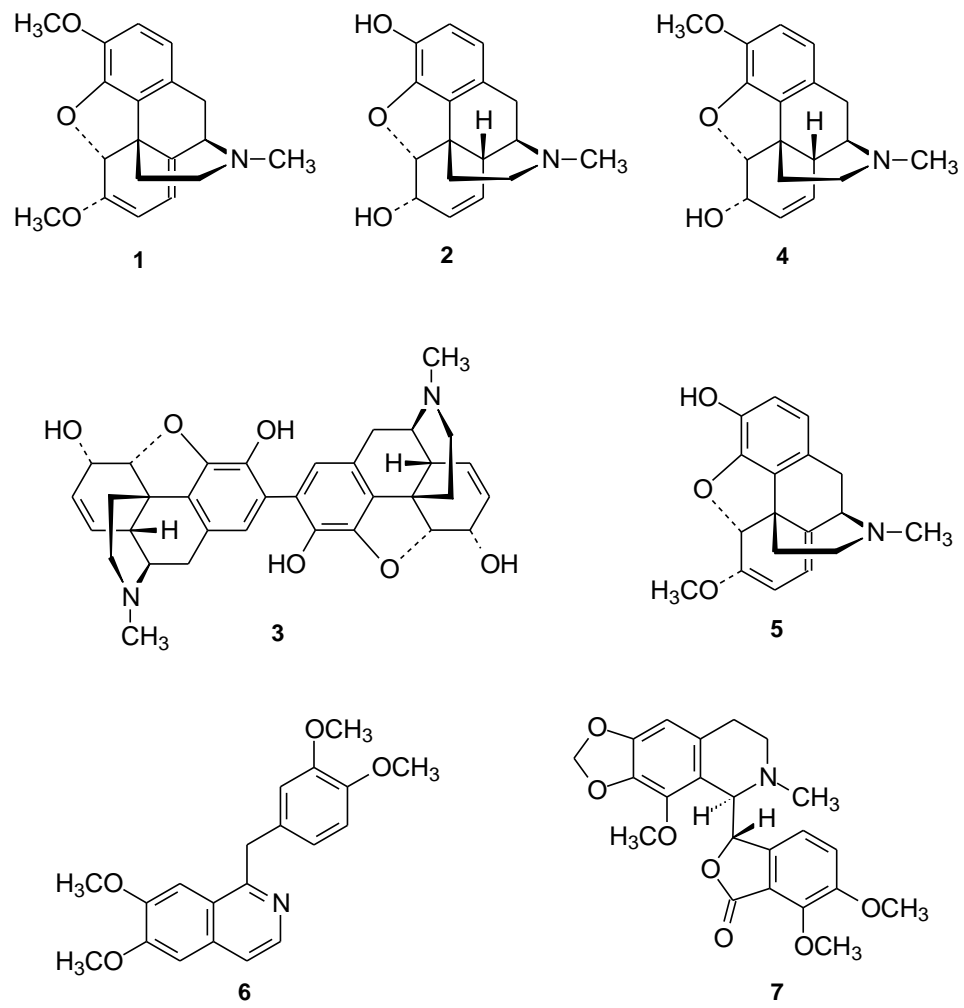

Fig. 2. Chemical structures of alkaloids present in Papaver somniferum L.: thebaine (1), morphine (2), pseudomorphine (3), codeine $(\mathbf{4})$, oripavine $(\mathbf{5})$, papaverine $(\mathbf{6})$ and noscapine $(\mathbf{7})$

Table 2

Physical properties of thebaine and related (investigated) alkaloids, taken from literature

\begin{tabular}{|c|c|c|c|c|c|c|}
\hline Num. & $\begin{array}{l}\text { Alkaloid trivial } \\
\text { name* }\end{array}$ & $\begin{array}{l}\text { Molecular } \\
\text { formula }\end{array}$ & $\begin{array}{l}\text { Molecular } \\
\text { weight }\end{array}$ & $\begin{array}{l}\text { CAS reg. } \\
\text { number }\end{array}$ & Melting point $\left({ }^{\circ} \mathrm{C}\right)$ & $\begin{array}{l}\text { Specific optical rotation } \\
{[\alpha]_{D}^{20}}\end{array}$ \\
\hline 1 & Thebaine & $\mathrm{C}_{19} \mathrm{H}_{21} \mathrm{NO}_{3}$ & 311 & $115-37-7$ & 193 & $\begin{array}{l}{[\alpha]_{D}^{15}-219(\mathrm{p}=2 \text { in }} \\
\text { ethanol })^{* *}\end{array}$ \\
\hline 2 & Morphine & $\mathrm{C}_{17} \mathrm{H}_{19} \mathrm{NO}_{3}$ & 285 & $57-27-2$ & $\begin{array}{l}254-256, \text { with dec. } \\
\text { (of monohydrate) }\end{array}$ & $\begin{array}{l}{[\alpha]_{D}^{25}-132(\text { methanol) for }} \\
\text { monohydrate }\end{array}$ \\
\hline 3 & Pseudomorphine & $\mathrm{C}_{34} \mathrm{H}_{36} \mathrm{~N}_{2} \mathrm{O}_{6}$ & 568 & $125-24-6$ & $\begin{array}{l}327, \text { dec. } \\
\text { (of trihydrate) }\end{array}$ & / \\
\hline 4 & Codeine & $\mathrm{C}_{18} \mathrm{H}_{21} \mathrm{NO}_{3}$ & 299 & $76-57-3$ & $154-156$ & $\begin{array}{l}{[\alpha]_{D}^{15}-136(\mathrm{c}=2 \text { in etha- }} \\
\text { nol })^{* *} \text { for monohydrate }\end{array}$ \\
\hline 5 & Oripavine & $\mathrm{C}_{18} \mathrm{H}_{19} \mathrm{NO}_{3}$ & 297 & $467-04-9$ & $200-201$ & {$[\alpha]_{D}^{20}-211.8$} \\
\hline 6 & Papaverine & $\mathrm{C}_{20} \mathrm{H}_{21} \mathrm{NO}_{4}$ & 339 & $58-74-2$ & $\begin{array}{l}\text { 147, from alcohol } \\
\text { and ether }\end{array}$ & 0 \\
\hline 7 & Noscapine & $\mathrm{C}_{22} \mathrm{H}_{23} \mathrm{NO}_{7}$ & 413 & $128-62-1$ & 176, dec. & $\begin{array}{l}{[\alpha]_{D}^{a a}+32(\mathrm{c}=4.56 \text { in }} \\
\text { water }) * * \text { for hydrochloride }\end{array}$ \\
\hline
\end{tabular}

* IUPAC names:

1. 6,7,8,14-tetradehydro-4,5 $\alpha$-epoxy- 3,6-dimethoxy-17-methylmorphinan

2. $(5 \alpha, 6 \alpha)$-7,8-didehydro- 4,5-epoxy-17-methylmorphinan-3,6-diol

3. $(5 \alpha, 6 \alpha)-2-[(5 \alpha, 6 \alpha)-3,6$-dihydroxy-17-methyl-7,8-didehydro-4,5-epoxymorphinan-2-yl]-17-methyl-7,8-didehydro-4,5epoxymorphinan-3,6-diol

4. $(5 \alpha, 6 \alpha)$-7,8-didehydro-4,5-epoxy-3-methoxy-17-methylmorphinan-6-ol

5. 6,7,8,14-tetradehydro-4,5 $\alpha$-epoxy-6-methoxy-17-methylmorphinan-3-ol

6. 1-(3,4-dimethoxybenzyl)-6,7-dimethoxyisoquinoline

7. (3S)- 6,7-dimethoxy-3-[(5R)-5,6,7,8-tetrahydro-4-methoxy-6-methyl-1,3-dioxolo(4,5-g)isoquinolin-5-yl]-1(3H)-isobenzofuranone

$* *(\mathrm{p}=2$ in alc. $)-2 \%$ solution of the substance in alcohol

$* *(\mathrm{c}=2$ in alc. $)-2 \%$ solution of the substance in alcohol

$* *(c=4.56$ in water $)-4.56 \%$ solution of the substance in water 
Additionally, there are many methods for determination of thebaine and other related opiates in biological samples like urine, or other liquids and tissues, as a result of drug or opiate use or abuse, with capillary electrophoresis method [31], gas chromatography-ion trap mass spectrometry (GC-MS) analysis [32], liquid chromatographicatmospheric pressure chemical ionization mass spectrometric analysis [33] or HPLC analysis [34, 35], GC-MS analysis [36-39]. Alkaloids are also being analyzed in environmental studies to trace the pollution of the environment [40].

Our primary interests were to develop appropriate "common" chromatographic methods (HPLC and GC) for analysis and determination of thebaine along with other related alkaloids such as morphine, codeine, oripavine, noscapine, papaverine, and pseudomorphine. Several methods were found in the literature including HPTLC (high-performance thin layer chromatography) [41], HPLC analysis [42-46] and GC determination [47-50].

The interest for developing a new method and procedure for thebaine analysis was primary because of absence of monograph in the European Pharmacopoeia and the need of easy, precise and fast methods that could be used for routine analysis. Most of the previously-mentioned methods use various techniques that are not so often present in standard pharmaceutical laboratories. On the other hand, HPLC and GC are the most widely used methods for qualitative and quantitative determinations. Of these two methods the HPLC methods are the most frequently used for alkaloids (either in free base or salt form). For several key alkaloids, such as morphine hydrochloride, morphine sulfate, codeine phosphate sesquihydrate that are given in the European Pharmacopoeia monographs, HPLC methods are available but they use ion pairing reagents and/or phosphate based buffers which are not suitable for HPLC-MS analysis.

On the other hand, hydrophobic counter-ions such as trifluoroacetate and formate in addition to ion-pairing with the positively charged solute also increase the affinity of the solute for the hydrophobic stationary phase and are also suitable for mass spectrometric detectors, being few of the $\mathrm{pH}$ adjusting reagents preferred [51].

Herein we present a rapid, easy to perform HPLC-UV method for determination of thebaine and characterization of impurities, with satisfactory separation of the other related alkaloids, that is transferable to HPLC-MS systems which could provide additional identification of impurities. Additionally, complementary GC-MS method was developed for identification of thebaine and poten- tial impurities. Together with well-defined methods for characterization of thebaine, such as melting point, optical rotation, UV-Vis and IR spectroscopy, these developed methods will be quite suitable for assessment of the quality of the isolated/prepared thebaine.

\section{EXPERIMENTAL}

\subsection{Instrumentation}

The chromatographic analyses were performed on a Hitachi VWR Chromaster Liquid Chromatography System equipped with a low pressure quaternary pump 5110 with integrated degaser, an autosampler with cooling option 5210, thermostated column compartment 5310, UV-VIS detector 5420 and EZChrom Elite software. For the dissolution of the stock and sample solutions, an Elma ultrasonic bath was used. The investigations were carried out on an Onyx monolithic C18 100 $\mathrm{mm} \times 4.6 \mathrm{~mm} \times 5 \mu \mathrm{m}$, analytical column (Phenomenex) at $20^{\circ} \mathrm{C}$. For recording the PDA spectra Shimadzu Nexera UHPLC system was used with binary pumps LC-30AD (× 2), DGU20A 5R Degassing unit, SIL-30AC Autosampler, column heater CTO-20A, SPDM-20A PhotoDiode Array UV-Vis Detector and CBM-20A System controller. Gas chromatographic analyses were performed on Varian 450 GC system, equipped with 8410 autosampler and coupled with model $300 \mathrm{EI} / \mathrm{CI}$ MSD (mass detector). VF-5MS column (30 $\mathrm{m} \times 0.25 \mathrm{~mm}, 0.25 \mu \mathrm{m}$ film thickness) was employed and helium was used as carrier gas.

For determination of the physicochemical properties of thebaine the following instruments were used: Büchi 545 instrument for melting point determination, Varian Excalibur 3100 FTIR spectrophotometer equipped with ZnSe ATR accessory for acquisition of FT-IR-ATR spectra, Varian Cary 50 Spectrophotometer for obtaining the UV spectra, Metrohm pH-meter connected with Thiamo Software and Schmidt + Haensch polarimeter for the determination of the specific optical rotation of the samples.

\subsection{Chemicals and materials}

Three different batches of thebaine base (BI, B-II, B-III) with different purity profiles were produced as intermediate products in the production site for raw materials of Alkaloid AD Skopje. The batches were produced in different years and were with different purity. Morphine hydrochloride, codeine phosphate hemihydrate, noscapine 
and pseudomorphine standards were purchased from European Pharmacopoeia (the intended use of the standards is for related compound analysis and the exact content was within the limits specified by European Pharmacopoeia). Morphine base, oripavine and papaverine were produced in the manufacturing site of Alkaloid AD Skopje. Thebaine base that was used as control was supplied from LGC Standards, with purity of $99.0 \%$ (as provided). The chemical structures of the alkaloids, as free bases, are given in Figure 2. All reagents for HPLC analysis were with HPLC purity and obtained from Merck (Darmstadt, Germany). Purified water with high quality, produced in Alkaloid AD Skopje was used for the analyses. For gas chromatographic analyses methylene chloride from Merck was used as solvent.

\subsection{HPLC conditions}

The separation and analysis of thebaine were performed with a gradient method using $0.08 \%$ trifluoroacetic acid and $0.02 \%$ formic acid in deionized water (mobile phase A) and $0.08 \%$ trifluoroacetic acid and $0.02 \%$ formic acid in acetonitrile (mobile phase B). The mobile phases and solvents were filtered through $0.45 \mu \mathrm{m}$ filter. The gradient of the HPLC separating method is given in Table 3.

\section{Table 3}

\section{Developed gradient method for separation} of thebaine and its impurities

\begin{tabular}{cccc}
\hline \hline Time (min) & A\% & B\% & Flow (ml/min) \\
\hline 0.0 & 100 & 0 & 1.5 \\
10.0 & 80 & 20 & 2.0 \\
13.0 & 80 & 20 & 2.0 \\
15.0 & 100 & 0 & 1.5 \\
\hline \hline
\end{tabular}

The usual analysis run time was $15 \mathrm{~min}$. The injection volume was $10 \mu \mathrm{l}$. The detection wavelength was set at $285 \mathrm{~nm}$ (all UV scans of the examined alkaloids show $\lambda_{\max }$ at $285 \mathrm{~nm}$, except papaverine and noscapine, (which have $\lambda_{\max }$ at 310 $\mathrm{nm})$. Acetic acid (1\% v/v) was chosen as solvent for the samples and standards, having in mind the dissociation constant of thebaine and the information for the dissolution characteristic of thebaine and other alkaloids available in the literature [29].

\subsection{Preparation of solutions for HPLC}

All the solutions were prepared in $1 \%(\mathrm{v} / \mathrm{v})$ acetic acid. First the substance was dissolved in $10 \%(\mathrm{v} / \mathrm{v})$ acetic acid and then it was diluted to volume with distilled water to provide the desired concentration of the substance while making final concentration of $1 \%(\mathrm{v} / \mathrm{v})$ acetic acid. Different concentrations of samples and standards were prepared depending on their usage. Considering the molecular weights of the forms of the substances all solutions of the standards were prepared in three concentrations: $0.006 \mathrm{mg} / \mathrm{ml}, 0.25 \mathrm{mg} / \mathrm{ml}$ and $0.3 \mathrm{mg} / \mathrm{ml}$ concentration of free base in order to check the linearity of the method and to calculate the response factors. The concentrations of solutions are chosen in a way to provide sufficient information for their purpose. Considering the sample preparation of $4 \mathrm{mg} / \mathrm{ml}(100 \%)$, the 0.006 $\mathrm{mg} / \mathrm{ml}$ is $0.15 \%$, which is around the maximum concentration limit of which the unknown impurities are allowed to be present in the samples when analyzed for pharmaceutical purpose (the limit of unknown impurities is $0.1 \%$ ). The concentrations of $0.25 \mathrm{mg} / \mathrm{ml}$ and $0.3 \mathrm{mg} / \mathrm{ml}$ are $6.25 \%$ and $7.5 \%$ respectively, with reference to the $100 \%$ sample and were chosen in a way to provide good PDA (photo diode array) spectra and chromatography. Since the most usual maximal expected impurity concentration in some samples is $10 \%$, these three concentrations at the same time provide enough information to calculate the linearity of the method. For determination of retention times, solutions of $0.3 \mathrm{mg} / \mathrm{ml}$ on "as is" substance were prepared dissolving the substance in $2 \mathrm{ml}$ of $10 \%$ (v/v) acetic acid and then diluting to the mark with distilled water. The samples of three batches of thebaine that were subject of investigation and the control standard of thebaine from LGC $(99 \%)$ were prepared in concentration of $4 \mathrm{mg} / \mathrm{ml}$, providing sufficient concentration for the impurity profiles. Thebaine samples for obtaining UV spectra were also prepared in $1 \%(\mathrm{v} / \mathrm{v})$ acetic acid, but they were diluted to $0.006 \mathrm{mg} / \mathrm{ml}$ in order to provide satisfactory absorbance within the linear range. The $\mathrm{pH}$ of all of these samples was measured.

\subsection{HPLC method development}

During the development and optimization of the method different gradient methods were tested starting from $10 \%$ of mobile phase B at step 2 and going up to $30 \%$ mobile phase B. The flow was also tested- starting from linear throughout the method or gradient flow starting from 1 or $2 \mathrm{ml} / \mathrm{min}$ at step 1 and going up to $2.5 \mathrm{ml} / \mathrm{min}$ during the remainder of the analysis. The time gradient of the method was also optimized resulting in 4 steps in total, depending on the separation need, but also to obtain a rather fast run (not exceeding $15 \mathrm{~min}$ ). The last step 
was always used to turn the gradient to the starting point of $100 \%$ of mobile phase A. From all of the tested methods the one with the best separation of the impurities was selected (Table 3).

\section{6. $G C-M S$ analysis and sample preparation}

The GC analysis was performed in addition to the HPLC to provide sufficient identification of any present unknown impurities that need GC-MS analysis for their identification. The column used was VF-5MS column, 5\% phenyl-95\% dimethylsiloxane from Agilent $(30 \mathrm{~m}, 0.25 \mathrm{~mm}$ i.d. and $0.25 \mu \mathrm{m}$ film thickness). The carrier gas was helium with constant flow of $1.2 \mathrm{ml} / \mathrm{min}$. The injection mode with $1: 25$ split ratio and $1 \mu \mathrm{l}$ injection volume. Injector temperature was $260{ }^{\circ} \mathrm{C}$, high enough for vaporization of the alkaloids, but not high enough for thermal degradation [52]. The temperature program was set as follows: initial temperature of $160{ }^{\circ} \mathrm{C}$, held for $2 \mathrm{~min}$; ramped to $280{ }^{\circ} \mathrm{C}$ at $15{ }^{\circ} \mathrm{C} / \mathrm{min}$ and held $15 \mathrm{~min}$. The other relevant parameters were: scan time of $1 \mathrm{~s}$, MS source temperature of $250{ }^{\circ} \mathrm{C}$, detector voltage $1000 \mathrm{~V}$, ion source temperature of $250{ }^{\circ} \mathrm{C}$ and transfer line temperature of $280{ }^{\circ} \mathrm{C}$. All solutions were prepared in methylene chloride. Considering that the GC-MS analysis were performed just for qualitative purposes the concentrations were c.a. $0.05 \mathrm{mg} / \mathrm{ml}$.

\section{RESULTS AND DISCUSSION}

\subsection{Physicochemical characteristics}

Considering that the aim of the study was to define the parameters/characteristics and methods for the determination of purity of thebaine, it was started from the basic analyses of the substance, such as melting point determination, IR spectroscopy, UV spectroscopy and concluding with development of HPLC and GC methods. As a very simple analysis and initial indicator of purity, we started with determination of the melting point of the three different batches of thebaine manufac- tured by different routes. The reference value of $193{ }^{\circ} \mathrm{C}$ for melting point of thebaine free base was taken from the literature [5]. It can be seen that based on the melting point measurements the batch B-I is of highest purity (highest $\mathrm{mp}$ of $193.4{ }^{\circ} \mathrm{C}$ and narrowest temperature range $0.6{ }^{\circ} \mathrm{C}$ ). On the other hand, the batch of thebaine, B-II, is of lowest purity of the three analyzed samples (lowest $\mathrm{mp}$ of $189.9^{\circ} \mathrm{C}$ and widest temperature range of $2.5^{\circ} \mathrm{C}$ (Table 4). This shows that melting point can be a very good initial indicator of the substance purity. It is also noteworthy that B-II and B-III batches have different color (from grayish to brownish gray color).

According to Merck Index, the specific rotation $\left(589 \mathrm{~nm}, 20^{\circ} \mathrm{C}\right)$ of thebaine in ethanol is $-219^{\circ}$ $(20 \mathrm{mg} / \mathrm{ml})$. The specific rotation of all three batches was also determined, but gave satisfactory result just for the batch B-I of $-220.8^{\circ}$ (Table 4). For the other two batches the solutions were further diluted to concentration of $1 \mathrm{mg} / \mathrm{ml}$ and then measured. The specific rotation is also a good indicator of (optical) purity, taking into consideration that the other impurities present are optically active alkaloids with different specific rotation than the desired thebaine. The largest deviation from the literature value was observed for the sample B-II $\left(-138.5^{\circ}\right)$, but surprisingly it was very close to a value reported in the literature $\left(-134^{\circ}\right)$ by Maturová et al. for thebaine isolated from plant material [53].

The solubility of the thebaine and other alkaloids was investigated through a literature survey [29] and $1 \%(\mathrm{v} / \mathrm{v})$ acetic acid was determined as the best choice, which was then also experimentally proven. Thebaine and the other alkaloids are freely soluble in $1 \%(\mathrm{v} / \mathrm{v})$ acetic acid. The UV spectrum of thebaine commercial standard in $1 \%$ acetic acid was recorded and values of $\lambda_{\max }$ and $\log$ $\varepsilon$ were obtained ( $285 \mathrm{~nm}$ and 3.91 respectively). The three batches (B-I, B-II and B-III) were also analyzed by UV spectroscopy under identical conditions and the $\lambda_{\max }$ at $285 \mathrm{~nm}$ was observed for all of them. No shifts in $\lambda_{\max }$ were observed by changing the solvent polarity or $\mathrm{pH}$.

Table 4

Determined physical properties of the three examined batches of thebaine

\begin{tabular}{llccc}
\hline \hline $\begin{array}{l}\text { Batch of } \\
\text { thebaine }\end{array}$ & $\begin{array}{l}\text { Color/ } \\
\text { appearance }\end{array}$ & $\begin{array}{c}\text { Melting point } \\
\left({ }^{\circ} \mathbf{C}\right)\end{array}$ & $\begin{array}{c}\text { Specific optical rotation } \\
{[\alpha]_{D}^{20}(\text { abs. ethanol) }}\end{array}$ & $\begin{array}{c}\lambda_{\max }(\mathbf{n m}) * \\
(\mathbf{1 \%} \text { acetic acid) }\end{array}$ \\
\hline B-I & white powder & $192.8-193.4$ & $-220.8(2 \%)$ & 285 \\
B-II & grayish powder & $187.4-189.9$ & $-138.5(0.1 \%)$ & 285 \\
B-III & brownish-gray powder & $190.8-192.4$ & $-239.2(0.1 \%)$ & 285 \\
\hline \hline
\end{tabular}

$* \log \varepsilon$ of the thebaine standard in $1 \%$ acetic acid was 3.91 
In order to develop the most appropriate HPLC method, the UV spectra of thebaine and the other alkaloids were obtained utilizing the photo diode array (PDA) detector. The UV spectra of the three thebaine batches were obtained using $1 \%$ $(\mathrm{v} / \mathrm{v})$ acetic acid in and $\lambda_{\max }$ at $285 \mathrm{~nm}$ was observed in all cases (Table 4). Having in mind that UV spectra of all alkaloids and of thebaine in $1 \%$ $(\mathrm{v} / \mathrm{v})$ acetic acid, the HPLC analysis for their determination was carried out at $285 \mathrm{~nm}$. In addition, to confirm the specificity of the method, the UVPDAD was used to check the purity of the peaks. In the UV-PDA spectra of the other alkaloids (morphine, codeine, pseudomorphine, pholcodine, oripavine) also $\lambda_{\max }$ at $285 \mathrm{~nm}$ was observed, except for papaverine and noscapine that have $\lambda_{\max }$ at $310 \mathrm{~nm}$ in $1 \%(\mathrm{v} / \mathrm{v})$ acetic acid. These results con- firmed that the choice of monitoring wavelength $(285 \mathrm{~nm})$ for the HPLC method is valid.

The $\mathrm{pH}$ of the samples was also important in development of the method and was investigated. The $\mathrm{pH}$ of the samples dissolved in $1 \%(\mathrm{v} / \mathrm{v})$ acetic acid used for the UV spectroscopic studies was measured and ranged from 2.75 for the dilute samples to 3.0 for the more concentrated samples $(0.3$ $\mathrm{mg} / \mathrm{ml}$ ). Also, the combination of mobile phases (see Table 3) were prepared as in the gradient of the HPLC analysis. The $\mathrm{pH}$ of these solutions was also measured and was between 2 and 3 . All of the above-mentioned, went in favor of the selected mobile phases that provided low $\mathrm{pH}$, which ensured that thebaine and the other alkaloids would be completely protonated and be soluble in the mobile phase (Fig.3).

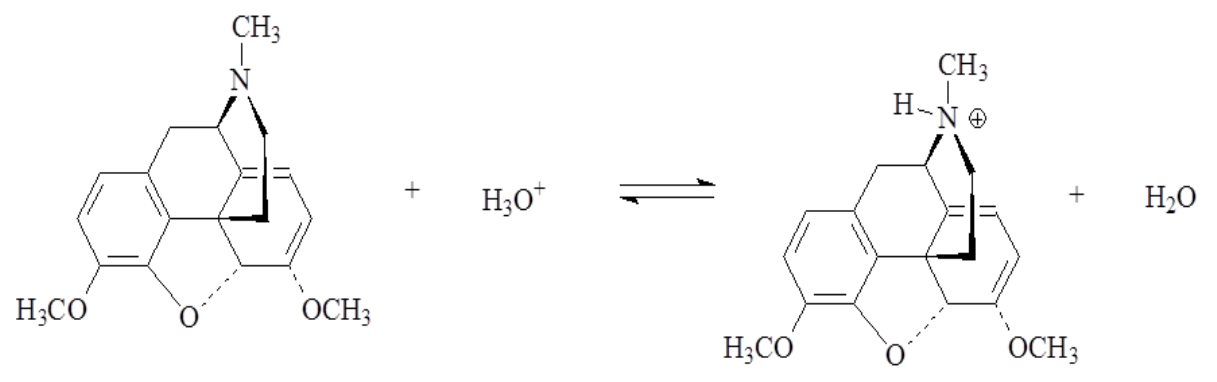

Fig. 3. Protonation of thebaine in aqueous solutions

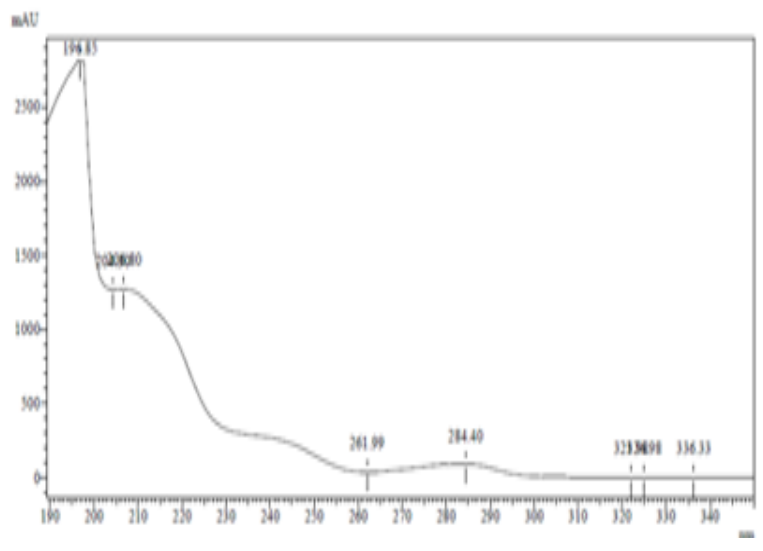

Fig. 4. UV (photo diode array, PDA) spectra of thebaine (0.3 $\mathrm{mg} / \mathrm{ml})$ obtained in $1 \%(\mathrm{v} / \mathrm{v})$ acetic acid

Furthermore the obtained IR spectra (ATR method, ZnSe crystal) of the three batches (Fig.7) were identical and matched those given in the literature [6], and matched the spectrum of the commercial standard of thebaine. This method is quite suitable for initial qualitative analysis and the FTIR-ATR is also suitable for direct analysis of the solid samples (without prior sample preparation), and to potentially detect different polymorphs or presence/absence of water. However, by using this method it is very difficult to detect and/or quantify impurities present in minute amounts.

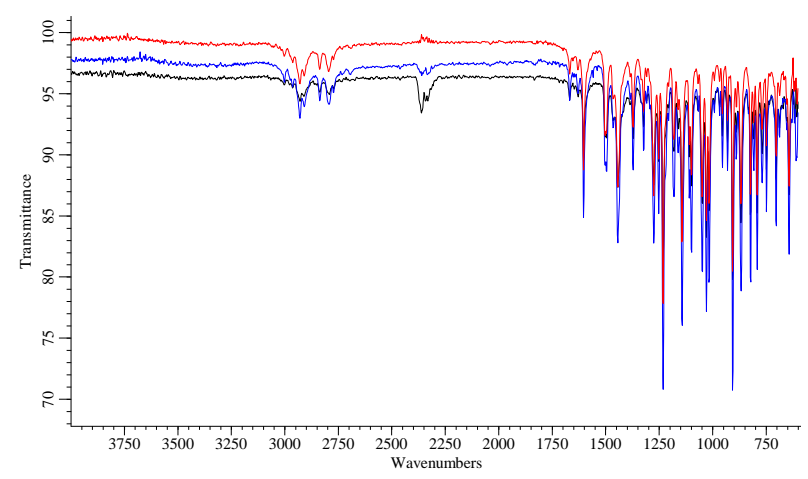

Fig. 5. FTIR-ATR spectra of the three batches of thebaine bases

(red trace B-I, blue trace B-II and black trace is B-III)

\subsection{HPLC method}

The developed HPLC method was first checked for specificity and for the abovementioned alkaloids it was found to be suitable. For determination of the system suitability and retention times of the potential components, a mixed 
standard of all the alkaloids (Fig. 6) was prepared and analyzed. The lowest resolution between two neighboring peaks was 1.0, between papaverine and noscapine peaks, and 1.6, between morphine and pholcodine, which was sufficient to provide good baseline separation according to the European Pharmacopoeia.

To prove the specificity of the method the relative retention times of the alkaloids were de- termined and for the purpose of quantitative analysis of thebaine, the response and corrections factors at the monitoring wavelength $(285 \mathrm{~nm})$ were determined. The relative retention times, correction factors, with respect to the thebaine peak, and the resolution between two neighboring peaks are given in Table 5.

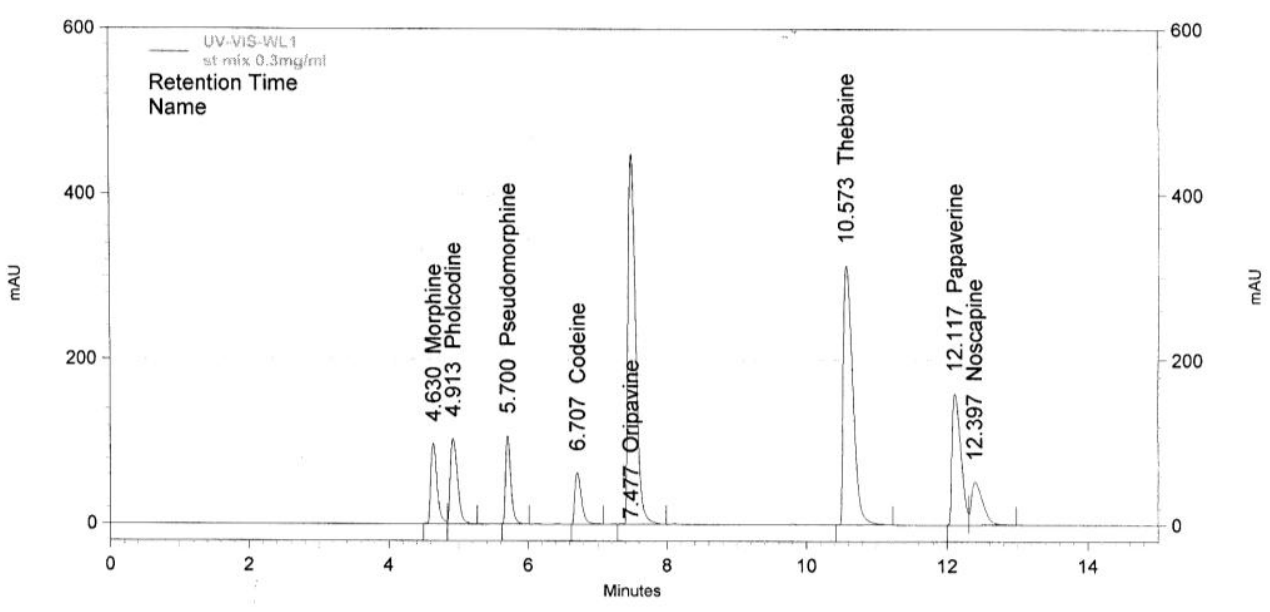

Fig. 6. Chromatogram of mixed standard solution of thebaine and related alkaloids with concentration of $0.3 \mathrm{mg} / \mathrm{ml}$, obtained with the method described in section 2.3 .

T a ble 5

Relative retention times, resolution and correction factors of the analyzed alkaloids determined from mixed standard solution with concentration of $0.3 \mathrm{mg} / \mathrm{ml}$

\begin{tabular}{cccc}
\hline \hline Name of component & Relative retention time & Resolution & Correction factors \\
\hline Morphine & $\sim 0.46$ & $/$ & 3.3 \\
Pholcodine & $\sim 0.47$ & 1.6 & 3.3 \\
Pseudomorphine & $\sim 0.56$ & 4.8 & 2.7 \\
Codeine & $\sim 0.65$ & 6.4 & 4.1 \\
Oripavine & $\sim 0.72$ & 3.9 & 0.8 \\
Thebaine & 1 & 13.2 & $/$ \\
Papaverine & $\sim 1.15$ & 6.2 & 1.4 \\
Noscapine & $\sim 1.17$ & 1.0 & 4.4 \\
\hline \hline
\end{tabular}

The three batches of thebaine (B-I, B-II and B-III) were analyzed utilizing the developed HPLC method (Fig 7-9) and the results are given in Table 6. From the obtained results it can be concluded that batch B-I is of highest purity $(99.90 \%)$, whereas batch B-II is of lowest purity $(97.25 \%)$. The impurities were identified based on their relative retention times assigned before and their UV spectra. In sample B-II seven impurities were detected of which three were identified as codeine, oripavine and papaverine. It is not unreasonable to propose that this batch was obtained via extraction from natural sources. It is interesting to note that there is correlation between the purity of the three thebaine batches obtained by HPLC and the melting point ranges previously determined. The advantage of this method is that it can be used for routine analysis (HPLC-UV), but also considering the mobile phase compatibility, it can be adapted/transferred easily for HPLC-MS analysis, especially if the identity of the impurities needs to be determined. 


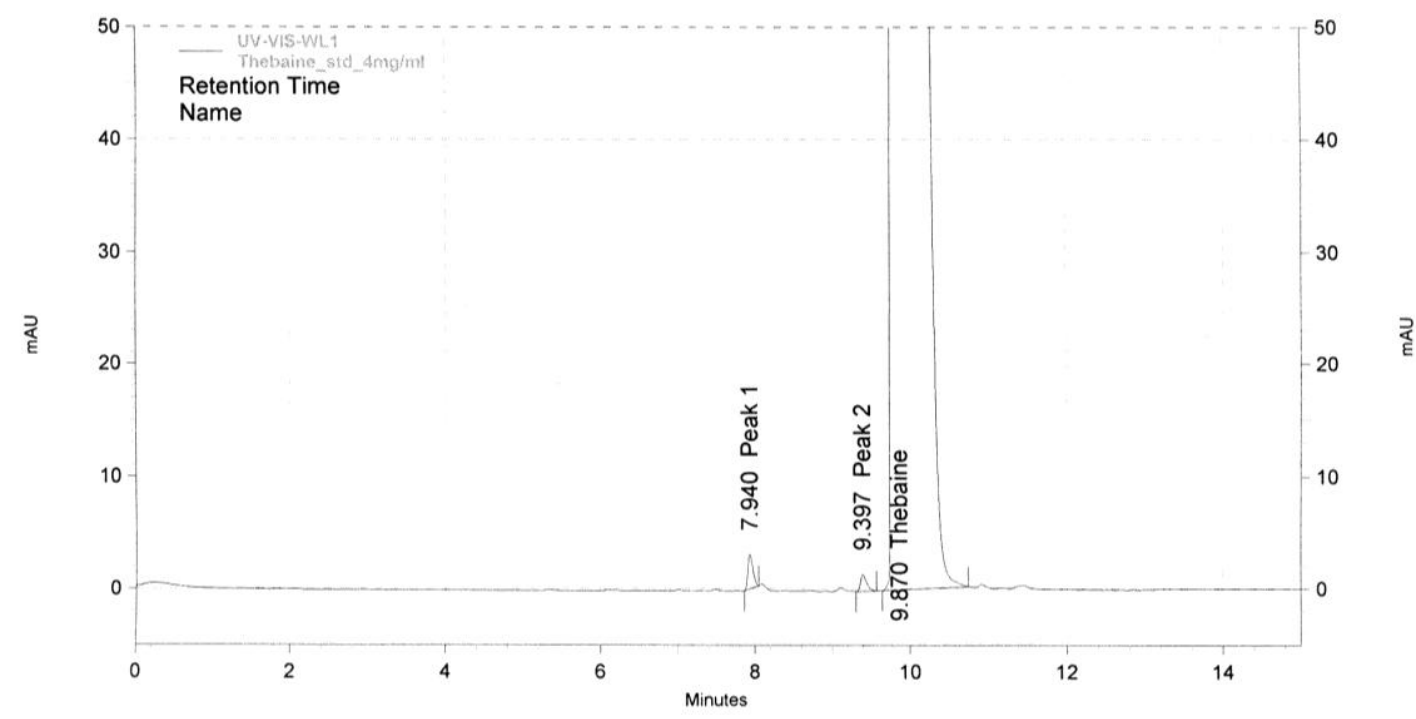

Fig. 7. Chromatogram of thebaine sample B-I (concentration of $4 \mathrm{mg} / \mathrm{ml}$ in $1 \%(\mathrm{v} / \mathrm{v}$ ) acetic acid)

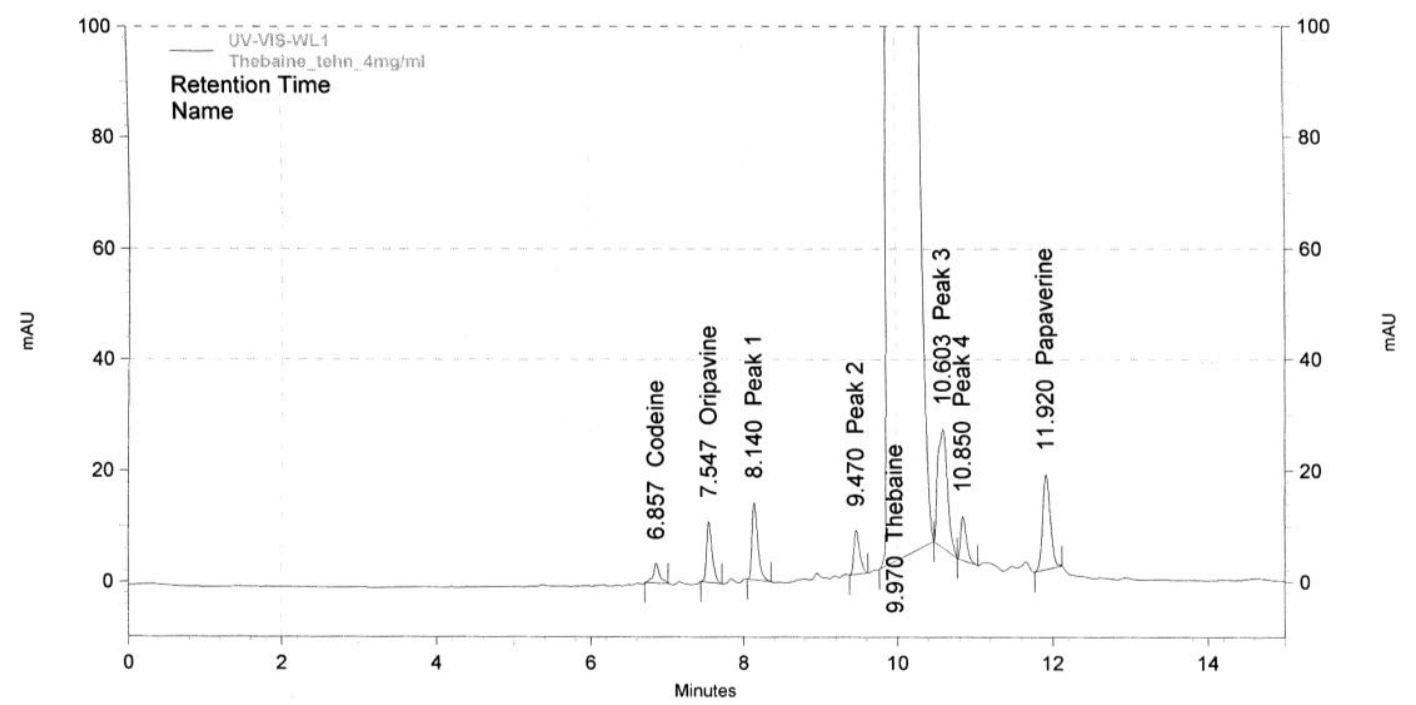

Fig. 8. Chromatogram of thebaine sample B-II (concentration of $4 \mathrm{mg} / \mathrm{ml}$ in $1 \%$ (v/v) acetic acid).

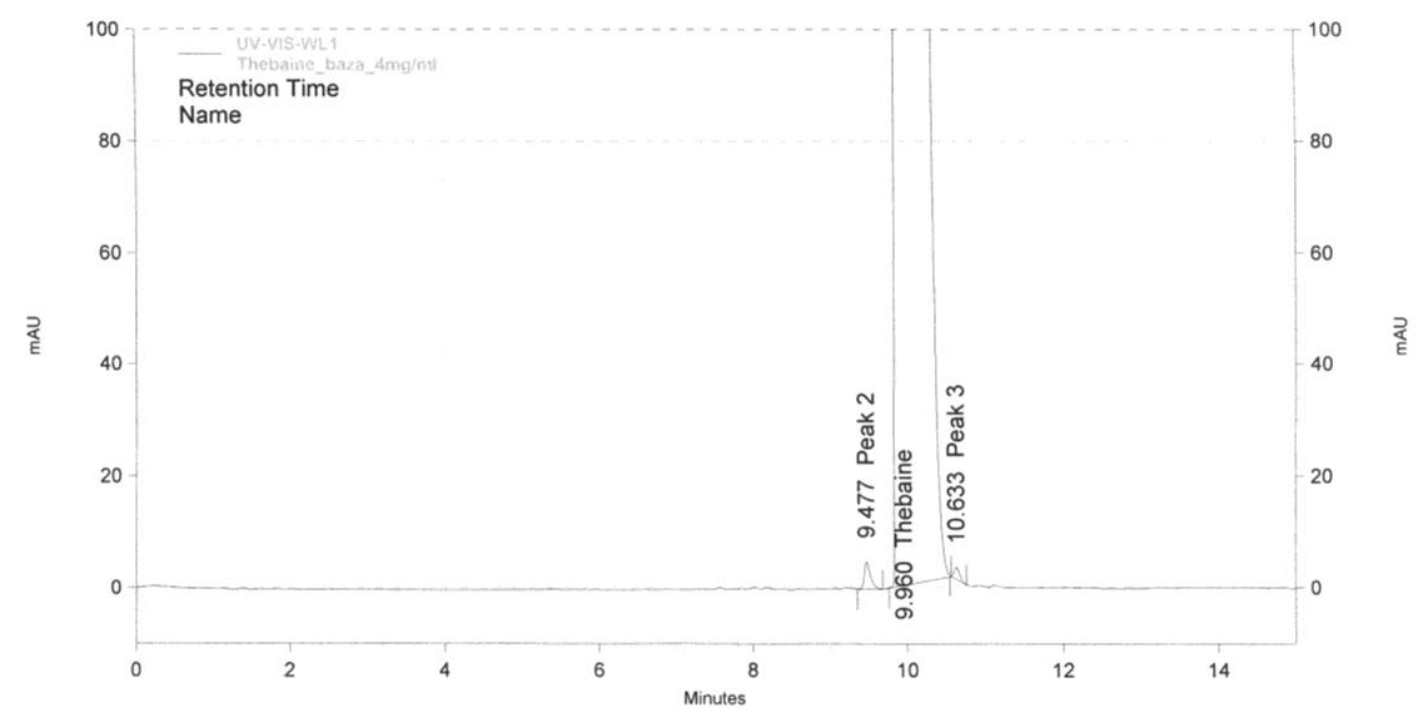

Fig. 9. Chromatogram of thebaine sample B-III (concentration of $4 \mathrm{mg} / \mathrm{ml}$ in $1 \%(\mathrm{v} / \mathrm{v}$ ) acetic acid) 
T a ble 6

HPLC properties of the three analyzed batches of thebaine. Area \% is calculated by normalization method

\begin{tabular}{cccccc}
\hline \hline Num. & Name of component & $\begin{array}{c}\text { Retention time } \\
(\mathbf{m i n})\end{array}$ & $\begin{array}{c}\text { B - I } \\
\text { Area \% }\end{array}$ & $\begin{array}{c}\text { B - II } \\
\text { Area \% }\end{array}$ & $\begin{array}{c}\text { B - III } \\
\text { Area \% }\end{array}$ \\
\hline $\mathbf{1}$ & Thebaine & $\sim 10(9.8-10.5)$ & 99.90 & 97.25 & 99.83 \\
$\mathbf{2}$ & Morphine & $\sim 5(4.6-5.2)$ & $/$ & $/$ & $/$ \\
$\mathbf{3}$ & Pseudomorphine & $\sim 6(5.7-6.1)$ & $/$ & $/$ & $/$ \\
$\mathbf{4}$ & Codeine & $\sim 7(6.7-7)$ & $/$ & 0.11 & $/$ \\
$\mathbf{5}$ & Oripavine & $\sim 7.5(7.4-7.7)$ & $/$ & 0.29 & $/$ \\
$\mathbf{U 1}$ & Unknown 1 & $\sim 8(7.9-8.1)$ & 0.06 & 0.38 & $/$ \\
$\mathbf{U} \mathbf{2}$ & Unknown 2 & $\sim 9.4(9.4-9.45)$ & 0.04 & 0.21 & 0.12 \\
$\mathbf{U 3}$ & Unknown 3 & $\sim 10.6(10.6-10.63)$ & $/$ & 0.95 & 0.05 \\
$\mathbf{U 4}$ & Unknown 4 & $\sim 10.85$ & $/$ & 0.21 & $/$ \\
$\mathbf{6}$ & Papverine & $\sim 12(11.85-12.1)$ & $/$ & 0.60 & $/$ \\
$\mathbf{7}$ & Noscapine & $\sim 12.3(12.28-12.4)$ & $/$ & $/$ & $/$ \\
\hline \hline
\end{tabular}

\subsection{GC-MS method}

In order to confirm the identity of the impurities, the first choice for the identification would be to transfer the developed HPLC-DAD method analysis to HPLC-MS method. The GC-MS method was considered as an alternative after the HPLC analysis, if additional identification is needed. The GC-MS method was first checked for specificity for the above-mentioned alkaloids and was found to be suitable. Several related alkaloids, namely, pholcodine, codeine, morphine, thebaine, oripavine, papaverine and noscapine were analyzed by GC-MS and the chromatograms and the mass spectra were of excellent quality. The chromatogram and the mass spectrum of the analyzed thebaine sample are shown in Figure 10. Moreover, by using the developed GC-MS method, all of the potential impurities in thebaine can be separated. The retention times, relative retention times and the key mass spectral data are given in Table 7.

We have found that the key parameters were the initial temperature $\left(160{ }^{\circ} \mathrm{C}\right)$ and the final temperature $\left(280^{\circ} \mathrm{C}\right)$. Also the transfer line was set at $280{ }^{\circ} \mathrm{C}$ to ensure that there are no left over components that would interfere with the subsequent analysis. From our preliminary studies, we have concluded that pseudomorphine (3) could not be analyzed by our GC-MS method, even after TMS derivatization. This is due to its high molecular mass and low volatility of $\mathbf{3}$. Also, this method is only suitable for free amines (bases); their salts have to be properly treated and converted to the neutral (free base) form in order to be analyzed by GC-MS. The advantages of the GC-MS method over the HPLC methods are that the retention times are highly reproducible and the existence of extensive searchable EI mass spectral libraries, which makes the identification of thebaine and impurities straightforward.
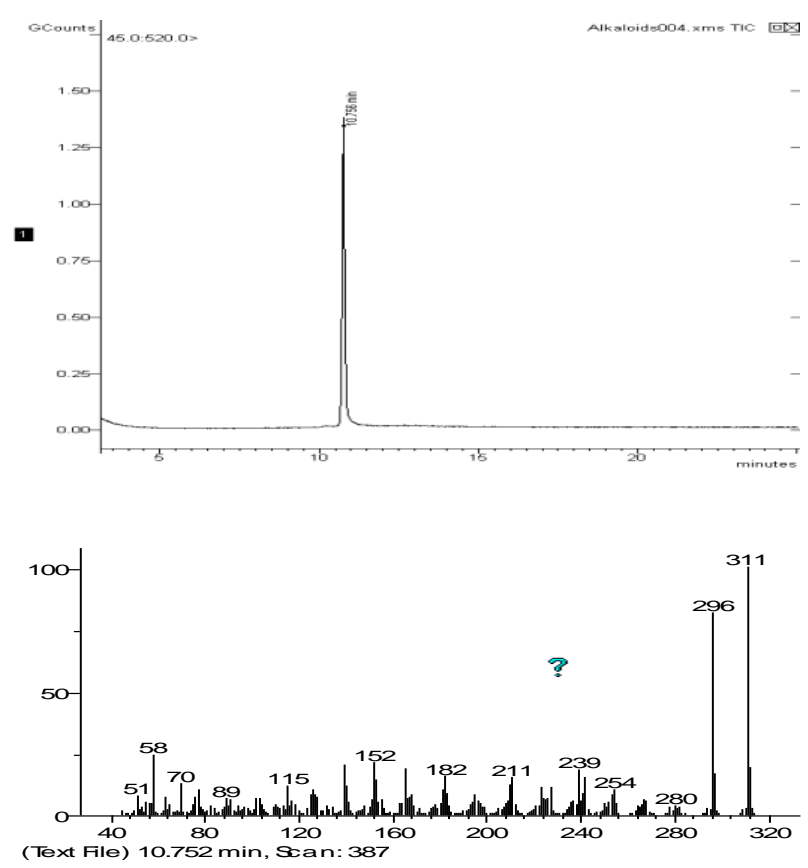

Fig. 10. Gas chromatogram (top) and experimentally obtained EI mass spectra (bottom) for thebaine, run with the developed GC-MS method

Overall for initial identification IR spectroscopy and UV spectroscopy are appropriate. If the instrument is available, the developed GCMS method can be used for initial identification and "rough" purity assesment. The HPLC method herein presented is suitable for routine quantitative analysis regardless of the method of preparation and it suitable for thebaine as a free base or as salt. The melting point and specific rotation measurements are quite useful as the first indicators of purity of thebaine. It is interesting to note that there was corelation between the purity, as determined by HPLC and the melting point ranges of the thebaine batches. 
Table 7

Retention times, relative retention times, and mass spectral data from the analyzed thebaine and related alkaloids using the developed GC-MS method

\begin{tabular}{ccccl}
\hline \hline Num. & Name of component & $\begin{array}{c}\text { Retention } \\
\text { time (min) }\end{array}$ & $\begin{array}{c}\text { Rel. ret } \\
\text { time }\end{array}$ & \multicolumn{1}{c}{$\begin{array}{c}\text { Mass spectral data } \\
(\boldsymbol{m} / \boldsymbol{z}, \text { rel. abundance \%) }\end{array}$} \\
\hline $\mathbf{1}$ & Thebaine & 10.752 & 1 & $\mathrm{M}^{+}(311,100) ; \mathrm{M}^{+}+1(312,20) ; \mathrm{M}^{+}-15(296,77)$ \\
$\mathbf{2}$ & Morphine & 10.317 & 0.96 & $\mathrm{M}^{+}(285,100) ; \mathrm{M}^{+}+1(286,20) ;(215,21) ;(162,25)$ \\
$\mathbf{3}$ & Pseudomorphine & n.d. & $/$ & $\mathrm{M}^{+}(568,57) ; \mathrm{M}^{+}+1(569,21) ;(215,21) ;(162,21)$ \\
$\mathbf{4}$ & Codeine & 9.981 & 0.93 & $\mathrm{M}^{+}(299,100) ; \mathrm{M}^{+}+1(300,20) ;(229,28) ;(162,51)$ \\
$\mathbf{5}$ & Oripavine & 10.490 & 0.975 & $\mathrm{M}^{+}(297,100) ; \mathrm{M}^{+}+1(298,20) ; \mathrm{M}^{+}-1(296,19)$ \\
$\mathbf{6}$ & Papverine & 13.423 & 1.25 & $\mathrm{M}^{+}(339,76) ; \mathrm{M}^{+}+1(340,15) ; \mathrm{M}^{+}-1(338,100) ;(308,25)$ \\
$\mathbf{7}$ & Noscapine & 18.823 & 1.75 & $\mathrm{M}^{+}(412,0.5) ;(220,100) ;(221,15)$ \\
$\mathbf{8}$ & Pholcodine & 19.376 & 1.80 & $\mathrm{M}^{+}(398,5.6) ;(114,100) ;(100,83)$ \\
\hline \hline
\end{tabular}

\section{CONCLUSIONS}

The initial studies were utilized for the development of the key HPLC-PDAD method which was shown to be specific and efficient to provide identification of thebaine and the other opium alkaloids, along with their quantification. Complementary GC-MS method was developed, primarily for qualitative analysis. Using the developed HPLC method three batches of thebaine were analyzed and their purity determined. Melting point determination and specific rotation are quite appropriate for preliminary purity assessment, along with IR and UV spectroscopy for preliminary identification. The additional analysis for identification of the present unknown impurities may be accomplished by transferring the herein presented HPLC-UV method to a HPLC-MS method.

\section{REFERENCES}

[1] T. Aniszewski, Alkaloids-Secrets of Life: Aklaloid Chemistry, Biological Significance, Applications and Ecological Role, Elsevier, 2007.

[2] L. L. C. Books, L. L. C. General Books, Natural Opium Alkaloids: Morphine, Thebaine, Codeine, Poppy Straw, Papaverine, Opiate, Oripavine, Scoulerine, Reticuline, Protopine, General Books.

[3] M. Hesse, Alkaloids: Nature's Curse or Blessing?, Wiley-VCH, 2002.

[4] M. F. Roberts, M. Wink, Alkaloids: Biochemistry, Ecology, and Medicinal Applications, Springer, 1998.

[5] M. J. O'Neil (ed.), The Merck Index: An encyclopedia of chemicals, drugs, and biologicals. $14^{\text {th }}$ ed., Whitehouse Station, NJ 2006.

[6] A. C. Moffat, M. D. Osselton, B. Widdop,: Clarke's Analysis of Drugs and Poisons, 3rd ed. Pharmaceutical Press: London, 2004.
[7] V. Gambaro, P. Minghetti, S. Arnoldi, M. Colombo, L. Dellacqua, A. Casiraghi, K. Guerrini, F. Fare, G. Roda, Analysis of fluid extracts obtained from Papaver rhoeas petals contaminated with Papaver bracteatum petals, Planta Med., 78(12), 1395-1398 (2012).

[8] M. Omidi, F. Koohzadi, M. Solouki, R. Taghizad Farid, H. Alizadeh, Comparison of morphinan alkaloids during different stages of growth in the medicinal plant opium poppy (Papaver somniferum L.), J. Med Plants, 11(44), 140-148 (2012).

[9] Y. Shoyama, F. Kawachi, H. Tanaka, R. Nakai, T. Shibata, K. Nishi, Genetic and alkaloid analysis of Papaver species and their F1 hybrid by RAPD, HPLC and ELISA, Forensic Sci. Int., 91(3), 207217 (1998).

[10] I. Stranská, M. Skalický, J. Novák, E. Matyášova, V. Hejnak, Analysis of selected poppy (Papaver somniferum L.) cultivars: Pharmaceutically important alkaloids, Industrial Crops and Products, 41(0), 120-126 (2012).

[11] Z. Szucs, B. Szabady, M. Szatrndry, G. Cirnpan, S. Nyiredy, High-throughput analytical strategy with combined planar and column liquid chromatography for improvement of the poppy (Papaver somniferum L.) with a high alkaloid content, Chromatographia, 56, 49-54 (2002).

[12] K. Yoshimatsu, F. Kiuchi, K. Shimomura, Y. Makino, A rapid and reliable solid-phase extraction method for high-performance liquid chromatographic analysis of opium alkaloids from Papaver plants, Chem. Pharm. Bull., 53(11), 14461450 (2005).

[13] D. Lavie, J. Rotman, A. Levy, D. Palevitch, A rapid quantitative method for the determination of thebaine in Papaver bracteatum, Phytochemistry, 18(12), 2011-2013 (1979).

[14] J. W. Costin, S. W. Lewis, S. D. Purcell, L. R. Waddell, P. S. Francis, N. W. Barnett, Rapid determination of Papaver somniferum alkaloids in 
process streams using monolithic column highperformance liquid chromatography with chemiluminescence detection, Anal. Chim. Acta, 597(1), 19-23 (2007).

[15] P. S. Francis, J. L. Adcock, J. W. Costin, S. D. Purcell, F. M. Pfeffer, N. W. Barnett, Chemiluminescence detection of opium poppy (Papaver somniferum) alkaloids, J. Pharm. Biomed. Anal., 48(3), 508-518 (2008).

[16] A. A. Ensafi, F. Hasanpour, T. Khayamian, A. Mokhtari, M. Taei, Simultaneous chemiluminescence determination of thebaine and noscapine using support vector machine regression, Spectrochim. Acta, Part A, 75(2), 867-871 (2010).

[17] N. W. Barnett, B. J. Hindson, S. W. Lewis, S. D. Purcell, Determination of codeine, 6-methoxycodeine and thebaine using capillary electrophoresis with tris(2,2'-bipyridyl)ruthenium(II) chemiluminescence detection, Anal. Commun., 35(10), 321-324 (1998).

[18] B. J. Hindson, P. S. Francis, S. D. Purcell, N. W. Barnett, Determination of opiate alkaloids in process liquors using capillary electrophoresis, $J$. Pharm. Biomed. Anal., 43(3), 1164-1168 (2007).

[19] M. Baranska, H. Schulz, A. C. Geoffrey, Chapter 4: Determination of Alkaloids through Infrared and Raman Spectroscopy, In: The Alkaloids: Chemistry and Biology. Academic Press, pp 217-255 2009.

[20] A. Agnihotri, S. C. Tewari, P. Khatod, S. Banerjee, M. Balasubramanian, Determination of thebaine in crude thebaine samples by infrared and ultraviolet spectrophotometric methods, Analyst, 109, 14131416 (1984).

[21] G. W. Caldwell, A. D. Gauthier, J. E. Mills, Configurational analysis of thebaine, codeine and 14beta-hydroxycodeinone $N$-oxides, Magn. Reson. Chem., 34(7), 505-511 (1996).

[22] O. F. Ellingsen, K. E. Malterud, J. K. Wold, Studies on thebaine, III Oxidative colorimetric analysis of thebaine, Arch. Pharm., 318(4), 380-382 (1985).

[23] S. M. Han, N. Purdie, Simultaneous determination of opiates by circular dichroism, Anal. Chem., 58(1), 113-116 (1986).

[24] K. Ikonomovski, Colorimetric determination of thebaine in Papaver bracteatum, J. Pharm. Sci., 70(1), 102-103 (1981).

[25] D. K. Kuila, S. C. Lahiri, Search for suitable mobile phase in TLC analysis of different drugs of forensic interest and their gas liquid chromatographic experiment, J. Indian Chem. Soc., 84(1), 69-73 (2007).
[26] J. Pothier, N. Galand, Automated multiple development thin-layer chromatography for separation of opiate alkaloids and derivatives, $J$. Chromatogr., 1080(2), 186-191 (2005).

[27] Y. Shoyama, T. Fukada, H. Murakami, Production of monoclonal antibodies and ELISA for thebaine and codeine, Cytotechnology, 19(1), 55-61 (1995).

[28] N. W. Turner, M. Cauchi, E. V. Piletska, C. Preston, S. A. Piletsky, Rapid qualitative and quantitative analysis of opiates in extract of poppy head via FTIR and chemometrics: Towards in-field sensors, Biosensors Bioelectron., 24 (11), 3322-3328 (2009).

[29] G. E. Baiulescu, S. D. Popescu, Determination of codeine, dionin and thebaine by differential pulse polarography, Anal. Lett., 19(5-6), 587-596 (1986).

[30] B. Rezaei, S. Damiri, Development of a voltammetric procedure for assay of thebaine at a multi-walled carbon nanotubes electrode: Quantification and electrochemical studies, J. Solid State Electrochem., 14(6), 1079-1088 (2010).

[31] A. Alnajjar, A. M. Idris, M. Multzenberg, B. McCord, Development of a capillary electrophoresis method for the screening of human urine for multiple drugs of abuse, J. Chromatogr. B, 856(12), 62-67 (2007).

[32] G. Cassella, A. H. B. Wu, B. R. Shaw, D. W. Hill, The analysis of thebaine in urine for the detection of poppy seed consumption, J. Anal. Toxicol., 21(5), 376-383 (1997).

[33] R. Kikura-Hanajiri, N. Kaniwa, M. Ishibashi, Y. Makino, S. Kojima, Liquid chromatographicatmospheric pressure chemical ionization mass spectrometric analysis of opiates and metabolites in rat urine after inhalation of opium, $J$. Chromatogr. B, 789(1), 139-150 (2003).

[34] M. Shamsipur Mojtaba, N. Fattahi, Extraction and determination of opium alkaloids in urine samples using dispersive liquid-liquid microextraction followed by high-performance liquid chromatography, J. Chromatogr. B, 879(28), 2978-2983 (2011).

[35] Y. R. Zhang, C. Liang, Q. Y. Jin, Analysis of 39 drugs in urine by HPLC after solid-phase extraction, Chin J Forensic Med, 20(1), 14-16 (2005).

[36] B. M. El-Haj, A. M. Al-Amri, H. S. Ali, I. Ahmed, GC-MS detection and characterization of thebaine as a urinary marker of opium use, Forensic Toxicology, 25(2), 62-68 (2007).

[37] B. M. El-Haj, H. S. Ali, N. M. Hamoudi, Oripavine as a new marker of opiate product use, Forensic Toxicology, 29(2), 152-158 (2011).

[38] R. J. Lewis, R. D. Johnson, R. A. Hattrup, Simultaneous analysis of thebaine, 6-MAM and six 
abused opiates in postmortem fluids and tissues using Zymark $\hat{A} \circledast$ automated solid-phase extraction and gas chromatography-mass spectrometry, $J$. Chromatogr. B, 822(1-2), 137-145 (2005).

[39] C. Meadway, S. George, R. Braithwaite, Opiate concentrations following the ingestion of poppy seed products - Evidence for 'the poppy seed defence', Forensic Sci. Int., 96(1), 29-38 (1998).

[40] C. B. Bural, G. N. Demirer, O. Kantoglu, F. B. Dilek, Treatment of opium alkaloid containing wastewater in sequencing batch reactor (SBR)Effect of gamma irradiation, $R a P C, 79(4), 519$ $526(2010)$.

[41] K. Scheidl, F. Wurst, T. Prey, E. Bancher, Quantitative determination of thebaine in Papaver bracteatum. I. Chromatographic separation and in situ evaluation of HPTLC-plates, Fresen Z Anal Chem, 308(5), 428-430 (1981).

[42] G. Sariyar, A. Mat, H. F. Senol, The quantitative determination of thebaine and narcotine by HPLC in some Turkish Papaver species, Acta Pharmaceutica Turcica, 39(2), 73-75 (1997).

[43] S. Seidi, Y. Yamini, A. Heydari, M. Moradi, A. Esrafili, M. Rezazadeh, Determination of thebaine in water samples, biological fluids, poppy capsule, and narcotic drugs, using electromembrane extraction followed by high-performance liquid chromatography analysis, Anal. Chim. Acta, 701(2), 181188 (2011).

[44] M. P. Gomez-Serranillos, E. Carretero, A. Villar, A new HPLC method for the analysis of alkaloids in poppy straw, Fitoterapia, 66(2), 156-158 (1995).

[45] P. Gomez-Serranillos, E. Carretero, A. Villar, A study of phenanthrenic poppy straw alkaloids by reversed-phase HPLC, Acta Technologiae et Legis Medicamenti, 6(3), 337-342 (1995).

[46] L. Krenn, S. Glantschnig, U. Sorgner, Determination of the live major opium alkaloids by reversedphase high-performance liquid chromatography on a base-deactivated stationary phase, Chromatographia, 47(1-2), 21-24 (1998).

[47] M. Chiarotti, N. Fucci, M. I. Arufe Martinez, Analysis of illicit heroin origin impurities, derived from thebaine, by gas chromatography, Revista de Toxicologia, 6(3), 369-376 (1989).

[48] L. Iliev, L. Toteva, Determination of morphine, codeine and thebaine in some poppy varieties by gas chromatography, Farmatsiya, 31(4), 13-22 (1981).

[49] O. F. Ellingsen, J. K. Wold, B. S. Paulsen, Quantitative determination of thebaine in Papaver bracteatum Lindl. by an improved gas chromatographic procedure, Norvegica Pharm Acta, 45(3), 93-101 (1983).

[50] B. D. Paul, C. Dreka, E. S. Knight, M. L. Smith, Gas chromatographic/mass spectrometric detection of narcotine, papaverine, and thebaine in seeds of Papaver somniferum, Planta Med., 62(6), 544-547 (1996).

[51] T. Cecchi, Ion-Pair Chromatograpy and Related Techniques, CRC Press, Boca Raton, FL, 2009.

[52] R. Grob, E. Barry, Modern Practice of Gas Chromatography, $4^{\text {th }}$ ed., Wiley-Interscience, 2004.

[53] M. Maturová, D. Pavlásková, F. Santavý, Isolierung der Alkaloide aus einigen Arten der Gattung Papaver, Planta Med., 14(1), 22-41 (1966). 